\title{
Design and Optimization of the Antireflective Coating Properties of Silicon Solar Cells by Using Response Surface Methodology
}

\author{
Yahia F. Makableh ${ }^{1, * \mathbb{D}}$, Hani Alzubi ${ }^{2}$ and Ghassan Tashtoush ${ }^{2} \mathbb{D}$ \\ 1 Institute of Nanotechnology, Jordan University of Science and Technology, Irbid 22110, Jordan \\ 2 Mechanical Engineering Department, Jordan University of Science and Technology, Irbid 22110, Jordan; \\ hkalzubi17@eng.just.edu.jo (H.A.); gtash@just.edu.jo (G.T.) \\ * Correspondence: yfmakableh@just.edu.jo
}

Citation: Makableh, Y.F.; Alzubi, H.; Tashtoush, G. Design and Optimization of the Antireflective Coating Properties of Silicon Solar Cells by Using Response Surface Methodology. Coatings 2021, 11, 721. https://doi.org/10.3390/ coatings11060721

Academic Editor: Darius Milčius

Received: 17 May 2021

Accepted: 14 June 2021

Published: 16 June 2021

Publisher's Note: MDPI stays neutral with regard to jurisdictional claims in published maps and institutional affiliations.

Copyright: (c) 2021 by the authors. Licensee MDPI, Basel, Switzerland. This article is an open access article distributed under the terms and conditions of the Creative Commons Attribution (CC BY) license (https:// creativecommons.org/licenses/by/ $4.0 /)$.

\begin{abstract}
The design and optimization of a nanostructured antireflective coatings for Si solar cells were performed by using response surface methodology (RSM). RSM was employed to investigate the effect on the overall optical performance of silicon solar cells coated with three different nanoparticle materials of titanium dioxide, aluminum oxide, and zinc oxide nanostructures. Central composite design was used for the optimization of the reflectance process and to study the main effects and interactions between the three process variables: nanomaterial type, the radius of nanoparticles, and wavelength of visible light. In this theoretical study, COMSOL Multiphysics was utilized to design the structures by using the wave optics module. The optical properties of the solar cell's substrate and the three different nanomaterial types were studied. The results indicated that $\mathrm{ZnO}$ nanoparticles were the best antireflective coating candidate for $\mathrm{Si}$, as the $\mathrm{ZnO}$ nanoparticles produced the lowest reflection values among the three nanomaterial types. The study reveals that the optimum conditions to reach minimum surface reflections for silicon solar cell were established by using $\mathrm{ZnO}$ nanoparticles with a radius of $\sim 38 \mathrm{~nm}$. On average, the reflectance reached $\sim 5.5 \%$ along the visible spectral range, and approximately zero reflectance in the $550-600 \mathrm{~nm}$ range.
\end{abstract}

Keywords: antireflection coating; nanostructured materials; solar cells; response surface methodology (RSM)

\section{Introduction}

The consumption of electrical energy around the world has increased dramatically in recent decades, which led to increased demand for fossil fuel sources. Therefore, fossil fuels will no longer be available as sources of energy once a maximum rate of petroleum and gas extraction has been reached [1]. Hence, efforts are being made to reduce climate change and global warming related to this issue. For sustainable development, the practices of the reduction of greenhouse gas emissions and energy conservation have become compulsory. However, the enormous development in technology has led to support energy shortages and environmental issues. Alternative energy sources have become more popular in recent years due to the reduction in fossil fuel reserves and growing global warming concerns $[1,2]$. Most of the focus on renewable energy sources is on solar energy. Hence, there are two techniques that employ solar power, namely solar thermal and solar cells [3]. Energy from solar cells offers several advantages, such as low maintenance and eco-friendly solutions for the environment.

Different types of Si solar cells are widely used at different scales [4,5]. These solar cells are low cost, highly efficient, and long-lasting with a lifespan of around 20-25 years [6,7]. Yet, Si has high surface reflectivity, leading to large optical losses even with the current antireflection coatings (ARCs) used with commercial products [8,9]. Therefore, an optimized 
and highly efficient $\mathrm{ARC}$ is still required to be incorporated with Si solar cells to enhance their power conversion efficiency.

Nevertheless, even with the high open circuit voltage and photocurrent, Si solar cells still suffer from high optical losses due to surface reflections, which account for almost 37\% of losses from the incident light $[9,10]$. Possible solutions for this issue are the use of surface modification techniques such as using ARC to enhance solar cell light collection [11]. Different surface modification techniques were have been used to reduce the surface reflections of solar cells, such as using antireflection coatings by surface texturing [11], subwavelength structures [12], plasmonic surfaces [13], the surface passivation method [14], and the quarter wavelength method [15]. The use of ARCs can be carried out with single layer coatings, multilayer coatings, or by using nanostructured coatings [16-18].

Different types of nanostructures and nanomaterials have been used as antireflective coating layers [19]. Moreover, various materials, such as $\mathrm{ZnO}, \mathrm{Al}_{2} \mathrm{O}_{3}$, and $\mathrm{TiO}_{2}$, are of great interest due to their distinctive optical properties [16,18-20]. Nanoparticles with a spherical shape are under intensive investigation due to their optical properties for use as an ARC, as they do not directly depend on the light incident angle [21-23]. Due to its strong light scattering, suitable refraction index, and low incident light reflection capability, $\mathrm{ZnO}$ is widely used as an antireflective coating for different types of solar cells [19]. Additionally, these properties, in addition to high UV resistance, made $\mathrm{ZnO}$ the typical coating of choice for many applications [23-25]. On the other hand, $\mathrm{TiO}_{2}$, with its electrical, optical, and self-cleaning properties, make $\mathrm{TiO}_{2}$ nanoparticles an excellent candidate to be used as an ARC $[24,26]$. Moreover, $\mathrm{Al}_{2} \mathrm{O}_{3}$ thin film is an excellent candidate for Si solar cells when employed in different single or multilayer coatings [18,27].

Studying the factors and their colorations that affect the selection of nanoparticle size and type is vital for reaching minimum surface reflections, and can reduce a lot of the associated costs and experimental work related to lab trials $[19,28]$. Different methods can be utilized for this purpose, such as using response surface methodology (RSM), as this method has proven its efficacy in different fields [28,29]. The design of experiment (DOE) method is the most critical component in RSM utilization. The goal of DOE is to choose the most relevant points where the response should be well investigated and analyzed. Therefore, the selection of the design of the experiment has a great impact on defining the correctness of the surface response [30,31]. On the other hand, coupled with COMSOL Multiphysics analysis, the produced models can highly improve the design optimization and the selection of the type and size of the nanomaterials used.

In the current results, we report on the investigation of the factors affecting the Si surface reflections, taking into consideration the type of nanoparticles and the size of the nanoparticles. The response surface methodology technique was used to optimize the solar cell performance, by using the nanoparticles material type, and to identify the key variables associated with improving the performance yield in Si solar cells. There are many variations that could influence the solar cell efficiency. Consideration of all the possible important variations which can have large impact on the performance is the focal point. This study varied the nanomaterial type used as an ARC between three different materials (aluminum oxide, zinc oxide, and titanium dioxide), the diameter of the nanoparticles, and finally the wavelength of the visible light spectrum. In addition, interactions between these parameters, and their main effects on the solar cell performance, were considered in the optimization process. The optical models were built by using COMSOL Multiphysics. As a result, $\mathrm{ZnO}$ nanoparticles with radius $\sim 38 \mathrm{~nm}$ were found to produce minimum reflections in a wide spectral range.

\section{Materials and Methods}

This work investigated the effect of nanomaterials on the overall optical performance of Si solar cells. The proposed structures and the simulation analysis were developed in the COMSOL Multiphysics commercial package by using the wave optics module and 
electromagnetic wave frequency domain. Then, the results were optimized by using the response surface methodology technique.

\subsection{D Model Simulation and Analysis}

Antireflection coatings using nanostructures can be divided into homogenous and non-homogenous layers according to the size distribution [32-34]. The homogenous layers have an advantage of reducing the light reflection more than the non-homogenous layers. This can be attributed to the controlled effective change of the refractive index from air to the $\mathrm{Si}$ surface. Several homogenous geometries have been reported, such as using cubic, spherical, and pyramidal nanostructures as an ARC layer [34].

To better build and simulate the problem model, and to reduce any artificial reflections, certain boundary conditions were selected. For this purpose, the four sides of the domain were chosen to be periodic boundaries when building the model using COMSOL Multiphysics. Equal spacing between the selected nanostructures was also imposed to produce the required domain periodicity. With this taken into consideration, the incident electromagnetic waves appeared with the same angular position on the opposite side of the structure. The top and bottom boundaries were set as identical to mimic a real-life device with their absorption, reflection, and transmission of the electromagnetic waves. On the other hand, and to reduce the demand for more computational power, the total incident energy was accounted for, and the S-parameter method was used to calculate the values of both reflectance and transmittance. The slit port boundary condition was used for the bottom layer to account for the electromagnetic wave source

The dimensions of the Si part of the 2D structure were typically taken as $(8-104 \mathrm{~nm})$ in width and $300 \mathrm{~nm}$ in length; immersed in air as (8-104 nm) in width and $200 \mathrm{~nm}$ in length, whereas the radius of the nanoparticles was considered as $(5-50 \mathrm{~nm})$ for the case of the spherical shape. Figure 1 shows the 2D schematic structure of the selected nanoparticles that were used in the design and simulation processes.

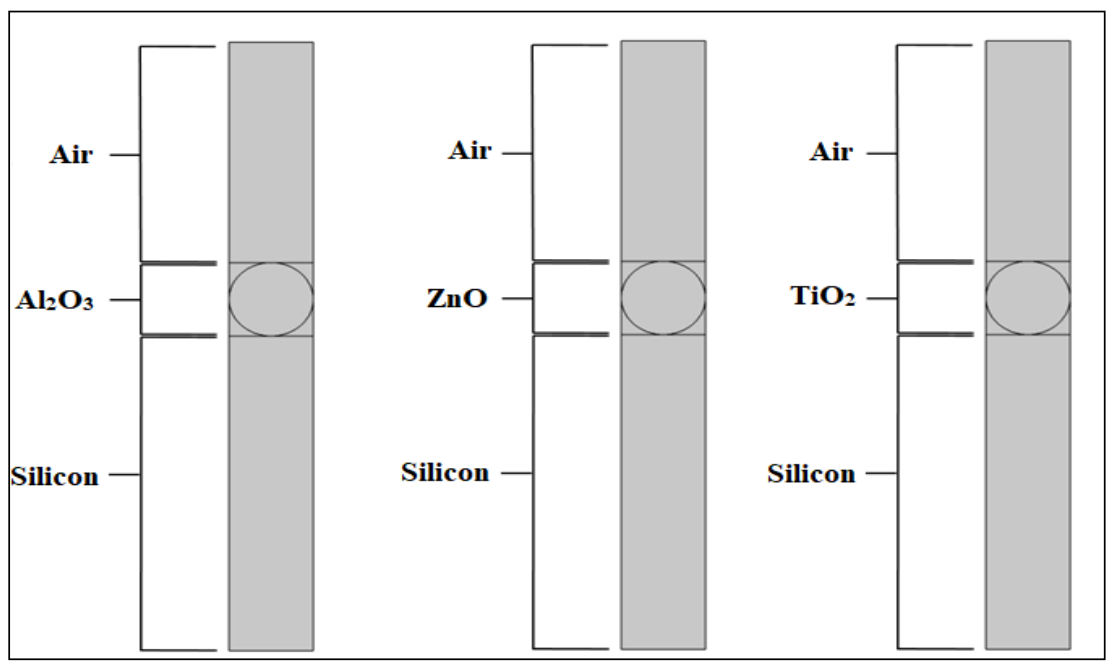

Figure 1. A schematic diagram showing the $\mathrm{Al}_{2} \mathrm{O}_{3}, \mathrm{TiO}_{2}$, and $\mathrm{ZnO}$ nanoparticle 2D model placed on top of a Si substrate.

\subsection{Operational Parameter Statistical Analysis}

A statistical factorial analysis was conducted to study the effect of the nanoparticle type and size to be used as an ARC for Si solar cells (geometrical nanostructure: spherical shape) to produce the minimum reflection value along the visible light spectrum. Moreover, the geometrical parameters, including the structural dimensions, were varied for the selected shape and size in order to understand the light-matter interaction from this perspective, hence optimizing the surface reflectivity of the solar cell. Furthermore, the changes in the reflectance over the considered spectral range were taken into consideration for each 
nanoparticle size under study. The optimal parameters used for reducing reflections from the solar cell surface by an antireflective coating were analyzed by a standard RSM design called central composite design (CCD).

\subsection{Continuous Factors}

In order to obtain an optimized design which can be used to enhance the solar cell's efficiency, and to reduce its reflectance, there are two continuous factors to be considered. One of them is the wavelength, which is considered to be in the range $(380-720 \mathrm{~nm})$, and the second one is the radius of the nanoparticle which is considered to be in the range $(5-50 \mathrm{~nm})$. The wavelength is usually the only factor studied in most studies, as it has great influence on the amount of light absorption [19,35]. Therefore, the influence of the wavelength range along the visible light spectrum is considered the most important parameter in solar cells' performance. In this research, the COMSOL Multiphysics model considers wavelengths ranging from $(380-720 \mathrm{~nm})$, with a step size equal to $10 \mathrm{~nm}$. The nanoparticles' sizes were varied in the range of $(5-50 \mathrm{~nm})$ to investigate the size effect in the selected spectral range by using RSM.

\subsection{Categorical Factors}

Three different types of nanomaterials were considered as an antireflective coating $\left(\mathrm{TiO}_{2}, \mathrm{Al}_{2} \mathrm{O}_{3}\right.$, and $\left.\mathrm{ZnO}\right)$ due to their distinctive optical properties and because their refractive indexes match for $\mathrm{Si}$. The average refractive indices in the desired spectral range of the considered materials $\left(\mathrm{Si}, \mathrm{Air}, \mathrm{Al}_{2} \mathrm{O}_{3}, \mathrm{TiO}_{2}\right.$, and $\mathrm{ZnO}$ ) are approximately 3.98, 1, 1.77, 2.61, and 2.02, respectively. Despite these values, and due to the change in the refractive index with the considered wavelength, the refractive indices were given as a set of data points as input to the model. Hence, the refractive index value designated for each considered wavelength value was accounted for. Factors affecting the final surface reflectance of the solar cell are not yet fully understood, and there is no way to connect these factors in direct relations. Explaining and clarifying these factors for optimization and implementation to increase the light absorption can highly reduce trial and error experiments and their associated costs.

Mathematical models describing the response were produced by using analysis of variance (full factorial), and experimental datasets were used to assess the fit of the models generated with the simulation data. For process optimization, 39 runs were used for a silicon solar cell with one replicate. Table 1 shows the process parameters and the considered ranges. Process parameters that were selected were nanoparticle radius, the wavelength spectrum, and nanomaterial type. In this RSM study, the considered levels were $4 \mathrm{~nm}, 11 \mathrm{~nm}, 28 \mathrm{~nm}, 45 \mathrm{~nm}$, and $52 \mathrm{~nm}$, in which both the $4 \mathrm{~nm}$ and $52 \mathrm{~nm}$ levels were outside the $(5-50 \mathrm{~nm})$ range in order to confirm the model validity at the boundaries.

Table 1. The model process parameters and ranges.

\begin{tabular}{cccc}
\hline Symbol & Process Parameter & Unit & Range \\
\hline A & Radius $(\mathrm{R})$ & $\mathrm{nm}$ & $5-50$ \\
\hline $\mathrm{B}$ & Wavelength $(\lambda)$ & $\mathrm{nm}$ & $380-720$ \\
\hline $\mathrm{C}$ & Nanomaterial type & - & $\mathrm{Al}_{2} \mathrm{O}_{3}, \mathrm{ZnO}, \mathrm{TiO}_{2}$ \\
\hline
\end{tabular}

\section{Results and Discussion}

\subsection{Interpretation of Regression Model and Analysis}

The analysis of variance (ANOVA) method was used to justify the suitability of the Si model. A reflectance model with a high $\mathrm{F}$ value and low $p$ value indicates significant factors. The $p$ value represents the probability of residual error involved in determining a certain factor as a significant factor. Normally, the effect of different factors must be below 0.05 in order to be considered as a significant factor, which represents a $95 \%$ confidence 
level. Table 2 displays the ANOVA for the second-order model proposed for reflectance given in the suggested model.

Table 2. Analysis of variance of silicon solar cell (reflectance model).

\begin{tabular}{cccccc}
\hline Source & DF & Adj SS & Adj MS & F-Value & $p$ Value \\
\hline Model & 11 & 0.535781 & 0.048707 & 12.33 & 0.0002 \\
\hline \multicolumn{5}{c}{ Linear } \\
\hline A, Radius (R) & 1 & 0.066718 & 0.066718 & 16.88 & 0.001 \\
\hline B, Wavelength $(\lambda)$ & 1 & 0.053480 & 0.053480 & 13.53 & 0.003 \\
\hline C, Nanomaterial type & 2 & 0.006938 & 0.003469 & 0.88 & 0.427 \\
\hline & 1 & 0.232468 & 0.232468 & 58.83 & $>0.001$ \\
\hline AA & 1 & 0.066449 & 0.066449 & 16.82 & $>0.001$ \\
\hline BB & \multicolumn{7}{c}{ Square } & \\
\hline AB & 1 & 0.091424 & 0.091424 & 23.14 & 0.011 \\
\hline AC & 2 & 0.032866 & 0.016433 & 4.16 & 0.027 \\
\hline BC & 2 & 0.013248 & 0.006624 & 1.68 & 0.206 \\
\hline
\end{tabular}

DF: degrees of freedom, SS: sum of squares, F: F-test value, and $p$ : error variance at a given response; parameters belonging to the filled cells are effective within $95 \%$ reliability interval.

Based on the results in Table 2, in the reflectance model of $\mathrm{Si}$ (F value 12.33, $p$ value 0.0002), all the main factors, $\mathrm{A}, \mathrm{B}, \mathrm{AA}, \mathrm{BB}, \mathrm{AB}$, and $\mathrm{AC}$, are significant with a $p$ value less than $0.05 \%$. The linear, square, and two-way interaction model equations were fitted for the reflectance response variable of silicon substrates. It is clear that the $p$ value of the reflectance model for $\mathrm{Si}$ is less than 0.05, showing that the model is significant with a confidence level of $\sim 95 \%$. The reflectance model of $\mathrm{Si}$ shows that the R-square value is $\sim 83.9 \%$. For each factor, the model was developed to produce certain values representing the best-case scenario.

The statistical factors were estimated by using ANOVA. From the central composite design output, and the values shown in Table 2, a second-order polynomial regression model equation was derived to define the response in terms of the independent factors. The proposed mathematical model of silicon substrate reflectance is presented in the following equation:

$$
\begin{aligned}
\text { Reflectance }(S i) & =X\left[1.175-0.00238(R)-0.00331(\lambda)+0.000365(R)^{2}+0.000004(\lambda)^{2}\right. \\
& -0.000043(R \lambda)] \\
& +Y\left[1.257+0.00287(R)-0.00377(\lambda)+0.000365(R)^{2}+0.000004(\lambda)^{2}\right. \\
& -0.000043(R \lambda)]+Z\left[1.163-0.00055(R)-0.00343(\lambda)+0.000365(R)^{2}\right. \\
& \left.+0.000004(\lambda)^{2}-0.000043(R \lambda)\right]
\end{aligned}
$$

where $Y$ : predicted reflectance response, $R$ : radius, $\lambda$ : wavelength, $(X, Y, Z)$ : dummy factor $\left(X: \mathrm{Al}_{2} \mathrm{O}_{3}, Y: \mathrm{TiO}_{2}, \mathrm{Z}: \mathrm{ZnO}\right)$. For example, if the material is $\mathrm{TiO}_{2}$, then $Y=1$, $(X$ and $Z)=0$.

\subsection{Estimation of Factor Effects}

Analysis of the surface reflectance model of $\mathrm{Si}$, and the effect of the independent factor data, began with the estimation of the effect of factors $\mathrm{A}, \mathrm{B}$, and C towards the response, which is the reflectance of the silicon surface, as shown in Table 2. From the ANOVA, it can be observed that factors A and B contribute the most significant effect toward output 
response, which is the reflectance. From the estimation effect analysis shown in Table 2, the normal plot for the standardized effects can be developed from the Pareto chart, as shown in Figure 2. The standardized effects show the significant factors towards the response "reflectance of silicon substrates", which are A, B, AB, AC, BB, and AA. Each of them represents radius, wavelength, interaction between radius and wavelength, and interaction between the radius and nanomaterial type.

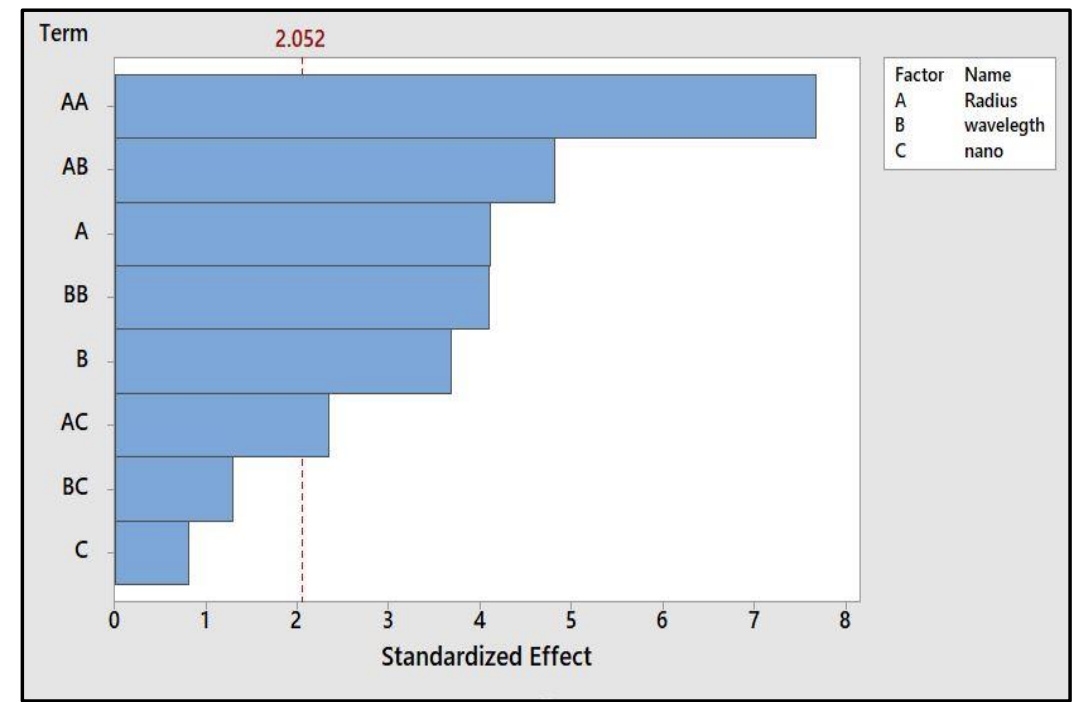

Figure 2. Pareto chart of the standardized effects of Si.

The guideline that was used for this analysis is based on a 95\% confidence level. If there are any effects exceeding the 2.052 line, the effect is considered significant. Figure 2 shows factors $\mathrm{AA}, \mathrm{AB}, \mathrm{A}, \mathrm{BB}, \mathrm{B}$, and $\mathrm{AC}$ that produce the most significant effects on the reflectance response. Based on the Pareto chart, factor $\mathrm{A}$, which is nanoparticle size, has a direct effect on the reflectance. By changing the nanoparticle size, the reflectance value changes accordingly. The size of the nanoparticles changes the effective refractive index when it changes from air $(n=1)$ to $\operatorname{Si}(n \sim 3.7)$ [36], as the nanoparticle coverage per unit area changes from smaller particles to larger particles [19,32,34]. However, according to the optical behavior of each material, different reflection values can be found from different materials at a certain considered nanoparticle size. On the other hand, factor B is found to have an effect on the reflectance response, which is the wavelength of the spectrum light. This factor is noted to be of great importance as different materials with different refractive indices have different reflectance values at each wavelength. These results are in agreement with published reports elsewhere $[37,38]$. Hence, the ARC behavior can be engineered in a selective manner to obtain a certain reflection level if needed for different applications, such as light reflectors, waveguides, or any other application that requires a certain level of reflectivity.

The Pareto chart displays the absolute value of factor effects. It can determine which factors have greater effects than others. The normal probability plot of the standardized effects was used to examine the magnitude and direction of factor effects on the surface reflectance of $\mathrm{Si}$, as shown in Figure 3. Factors further from 0.0 on the $x$-axis have greater magnitude and are more statistically significant. 


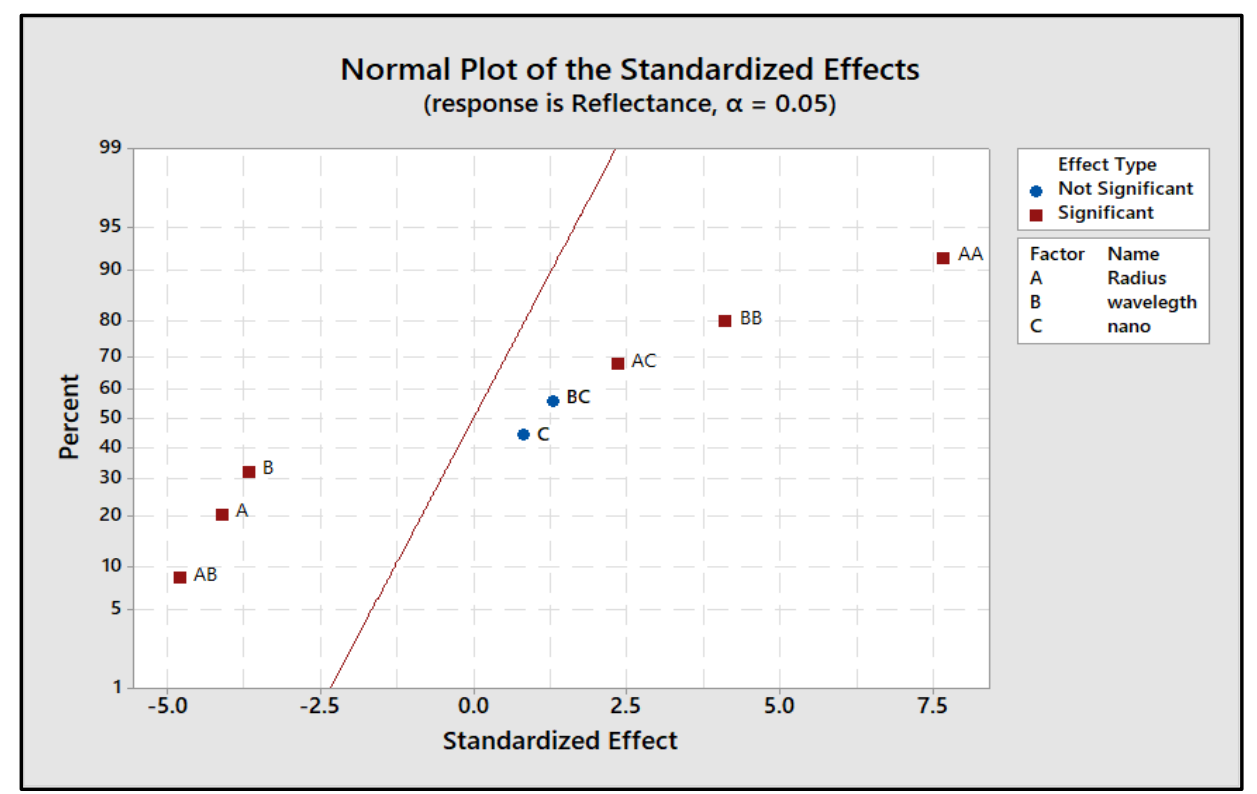

Figure 3. Normal plot of the standardized Si effects.

The direction of the main effects of all factors on the reflectance of the silicon cell was in agreement with the mathematical model equation described above. It is noted that the coefficients of $(R)^{2}$ and $(\lambda)^{2}$ both have positive values, which supports the location of AA and $B B$ on the right side from 0.0, as shown in Figure 3. Similarly, the negative effects of AB, $\mathrm{A}$, and $\mathrm{B}$ on the left side from 0.0 represents a decrease in the silicon cell reflectance, which can be achieved by increasing the values of $R, \lambda$, and $R \lambda$ as shown in the equation above. All the factors along the line can be ignored ( $\mathrm{BC}$ and $\mathrm{C}$ ). For the purpose of upgrading the model, factors $A C, B C$, and $C$ can be removed from the full model analysis, because they are not significant. In order to optimize the surface reflectivity of the solar cell, the changes in the reflectance over the considered spectral range were taken into consideration for each nanoparticle size in the range of $(5-50 \mathrm{~nm})$ in this study. The standard RSM design, which is called central composite design (CCD), was used to find the optimal parameters of the antireflective coating for reducing reflections from the solar cell surface, as described in the contour plots below for the three nanoparticles used in this study.

\subsection{Interpretation of Residual Plots}

In the ANOVA described above, it was assumed that all runs produced from the model were normally and independently distributed with the same variance at each level of the variables. These assumptions should be checked by examining the residuals and the residual plots produced from the ANOVA. A residual is the difference between each observation and its estimated (or fitted) value from the statistical model being studied [39]. These plots play an important role in assessing model adequacy and are used to examine the goodness-of-fit in regression. The normal probability plot of the residuals was used to verify the normality assumption. In this study, the normal probability plot of the residuals for the silicon cell followed a straight line, as shown in Figure 4a. If the residuals generally fall on a straight line, this indicates a good validity of the approximation of the linear regression model. In addition, a good variability between residuals and observation order is clear, as shown in Figure $4 \mathrm{~b}$. As the residuals fall in a horizontal band with no systematic pattern, no unusual structure is apparent, as shown in the versus order plot (Figure $4 b$ ). This means that the proposed model is adequate and there is no reason to presume any constant variance assumptions or violation of independence. 


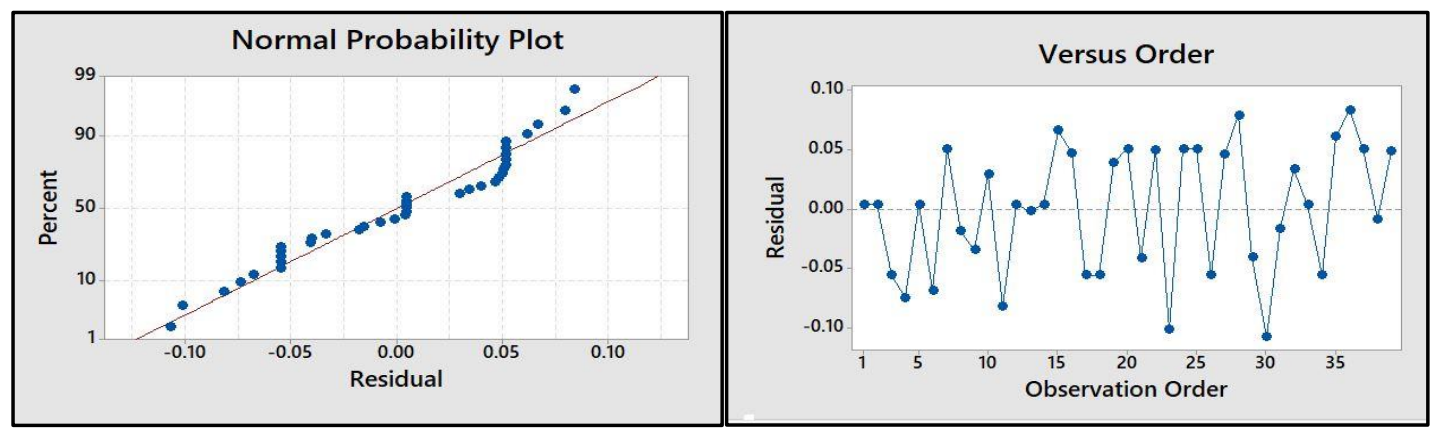

(a)

(b)

Figure 4. (a) Normal probability plot for standardized residuals of $\mathrm{Si}$, and (b) versus fits for standardized residuals of Si.

\subsection{Response Surface Methodology-Interpretation of Contour Plots}

\subsubsection{Aluminum Dioxide ARC Results}

The 2D contour plot of the $\mathrm{Al}_{2} \mathrm{O}_{3}$ nanoparticle ARC depicts the interactive effects of two variables and their individual effect on the reflectance of $\mathrm{Si}$, as shown in Figure 5. Here, the effects of the wavelength and the nanoparticle size of $\mathrm{Al}_{2} \mathrm{O}_{3}$ on the Si reflectance are presented. The minimum reflectance of $\mathrm{Si}(\sim 5.57 \%)$ was achieved at a wavelength of $\sim 644 \mathrm{~nm}$, with an $\mathrm{Al}_{2} \mathrm{O}_{3}$ nanoparticle radius of $\sim 41 \mathrm{~nm}$, while the maximum silicon cell reflectance ( $>50 \%$ ) was produced at wavelengths above $650 \mathrm{~nm}$ with an $\mathrm{Al}_{2} \mathrm{O}_{3}$ nanoparticle radius less than $12 \mathrm{~nm}$. Other published reports show $(\sim 5 \%)$ reflection achieved by using both $\mathrm{Al}_{2} \mathrm{O}_{3}$ and $\mathrm{TiO}_{2}$ as double layer coatings $[18,27]$ which, in general, can add more costs and complexity when used in an experimental setup. Therefore, the use of $\mathrm{Al}_{2} \mathrm{O}_{3}$ as a single layer ARC improves the overall process efficiency.

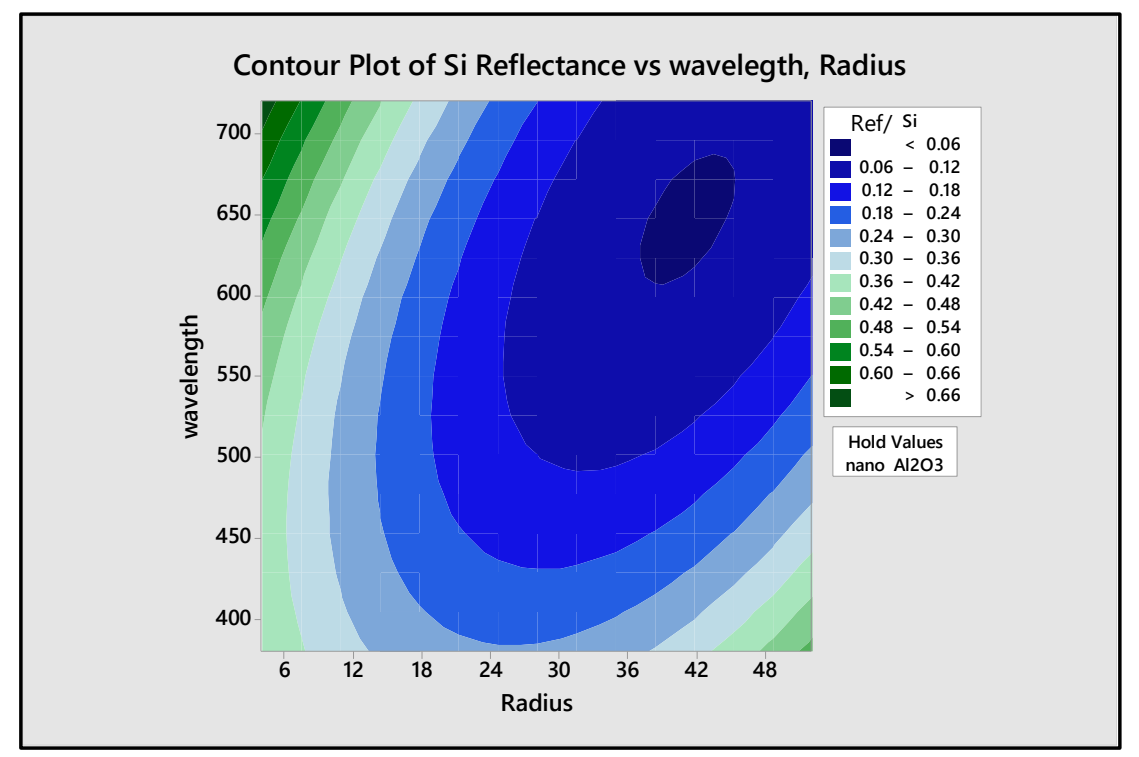

Figure 5. Contour plot of $\mathrm{Al}_{2} \mathrm{O}_{3}$ reflectance vs. wavelength and radius.

\subsubsection{Titanium Dioxide ARC Results}

Figure 6 shows the contour plot of $\mathrm{TiO}_{2}$ reflectance on $\mathrm{Si}$ with respect to nanoparticle size. From this figure, it can be seen that both wavelength and the $\mathrm{TiO}_{2}$ nanoparticle size have an influence on the surface reflectance of $\mathrm{Si}$. As the radius increases from 5 to $36 \mathrm{~nm}$, the surface reflectance of the silicon cell is decreased from the maximum, which is above $(60 \%)$, to the minimum value $(<6 \%)$. On the other side, in the region of wavelengths of less than $450 \mathrm{~nm}$ and with a radius more than $42 \mathrm{~nm}$, the reflectance increases dramatically. Moreover, the minimum reflectance of $\mathrm{Si}$ with $\mathrm{TiO}_{2}$ nanoparticles $(\sim 3.24 \%)$ was achieved 
at the wavelength of $675 \mathrm{~nm}$ and nanoparticles with a radius of $36 \mathrm{~nm}$, as shown in Figure 6 . The achieved reflection value can highly enhance the solar cell's efficiency when implemented in an experimental setup. Comparing the achieved value in this design with the $(\sim 5 \%)$ reflection by using double layers made of $\mathrm{Al}_{2} \mathrm{O}_{3}$ and $\mathrm{TiO}_{2}[18,27]$, or the $(\sim 7 \%)$ reflection by using a $\mathrm{TiO}_{2}$ single layer, gives the current results more significance for ARCs for Si $[20,26,40]$.

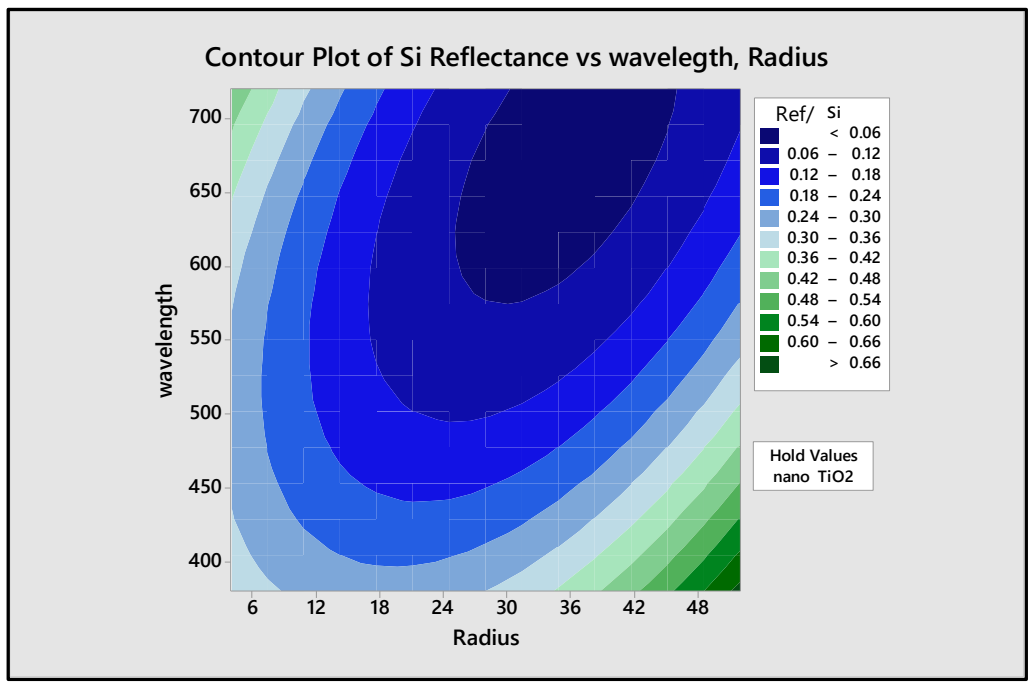

Figure 6. Contour plot of $\mathrm{TiO}_{2}$ reflectance vs. wavelength and radius.

\subsubsection{Zinc Oxide ARC Results}

Figure 7 shows the contour plot of $\mathrm{ZnO}$ nanoparticles on $\mathrm{Si}$, and the particle sizes with respect to the wavelength. Surface reflectance of $S i$ was decreased in the region of wavelengths ranging from $(550-720 \mathrm{~nm})$ and a $\mathrm{ZnO}$ particle radius from $(28-46 \mathrm{~nm})$ to less than $(6 \%)$, with minimum reflectance reaching $(0 \%)$ with a $\mathrm{ZnO}$ nanoparticle radius of $\sim 38 \mathrm{~nm}$ at a wavelength of $656 \mathrm{~nm}$. Achieving near zero reflection for Si is of great importance, as it enhances the light absorption in the device structure dramatically. In this context, Jalali Alireza et al. Han Seung-Yeol et al. and others reported, on average, (3-4\%) reflection values after using different sizes of $\mathrm{ZnO}$ nanoparticles as an ARC for $\mathrm{Si}$, while in the current results it has been shown that near zero reflection can be achieved by using $\mathrm{ZnO}$ nanoparticles as an ARC layer for Si [16,41-43].

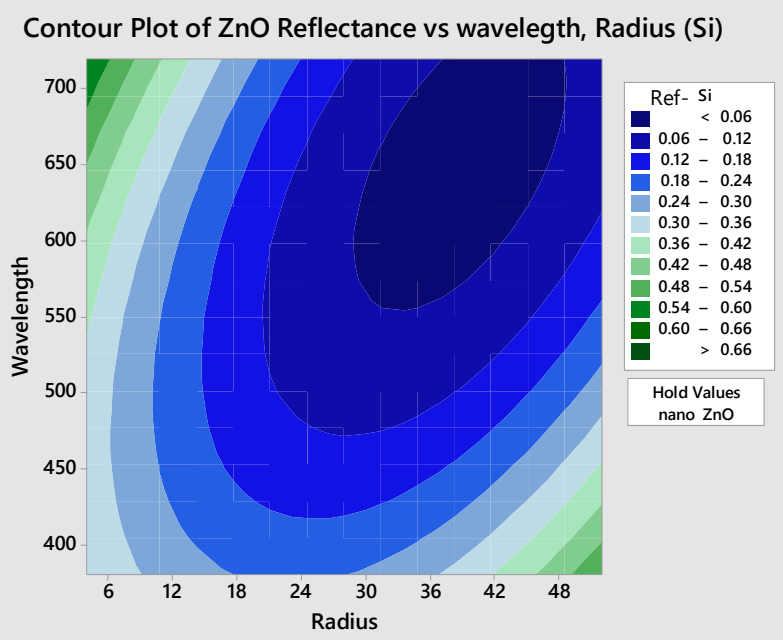

Figure 7. Contour plot of $\mathrm{ZnO}$ reflectance vs. wavelength and radius. 


\subsection{COMSOL Multiphysics Results}

The spectral range study was done from (380-720 nm) for all three nanoparticle types, $\mathrm{Al}_{2} \mathrm{O}_{3}, \mathrm{TiO}_{2}$, and $\mathrm{ZnO}$. The selected range is the range at which $\mathrm{Si}$ absorbs most of the light in the visible region to be converted into electrical power. The spherical structure shows different optical performances at different wavelengths. It is noted that the reflectance changes dramatically with the radius. The input parameters to the COMSOL model are shown in Table 3 below.

Table 3. Input parameters to the COMSOL Multiphysics model.

\begin{tabular}{|c|c|}
\hline Input Parameters & Details \\
\hline Geometry & Nanoparticle size range: $5-50 \mathrm{~nm}$ \\
\hline Nanoparticles Materials & $\mathrm{Al}_{2} \mathrm{O}_{3}, \mathrm{TiO}_{2}$, and $\mathrm{ZnO}$ \\
\hline Model Physics & $\begin{array}{l}\text { Electromagnetic wave frequency domain (emwf), } \\
\text { with the following boundary conditions: } \\
\text { - Top and bottom surfaces: Periodic } \\
\text { - Left and right sides: Floquet periodicity }\end{array}$ \\
\hline Mesh size & Physics-controlled mesh with element size (Fine) \\
\hline Study & $\begin{array}{l}\text { • Type: Wavelength domain } \\
\bullet \quad \text { Unit: } \mathrm{nm} \\
\text { - Range: } 380-720 \mathrm{~nm} \text {, with resolution: } 10 \mathrm{~nm}\end{array}$ \\
\hline
\end{tabular}

However, $\mathrm{ZnO}$ nanoparticles with a radius of $\sim 38 \mathrm{~nm}$ showed a better reflection reduction when compared to the other studied types. The reflectance spectra of pristine $\mathrm{Si}$ and $\mathrm{Si}$ with $\mathrm{ZnO}$ nanoparticles are shown in Figure 8 below. The results reveal an average reflection percentage of $(5 \%)$ along the selected spectral range, and approximately zero reflectance in the range $(550-600 \mathrm{~nm})$, which is in agreement with the RSM results. Table 4 shows summarized reflectance values for $\mathrm{ZnO}$ nanoparticles at different spectral ranges. With these results, it has been shown that $\mathrm{Si}$ can absorb most of the incident light found in the visible region when the $\mathrm{Si}$ has the highest external quantum efficiency. Hence, better power conversion efficiency can be obtained.

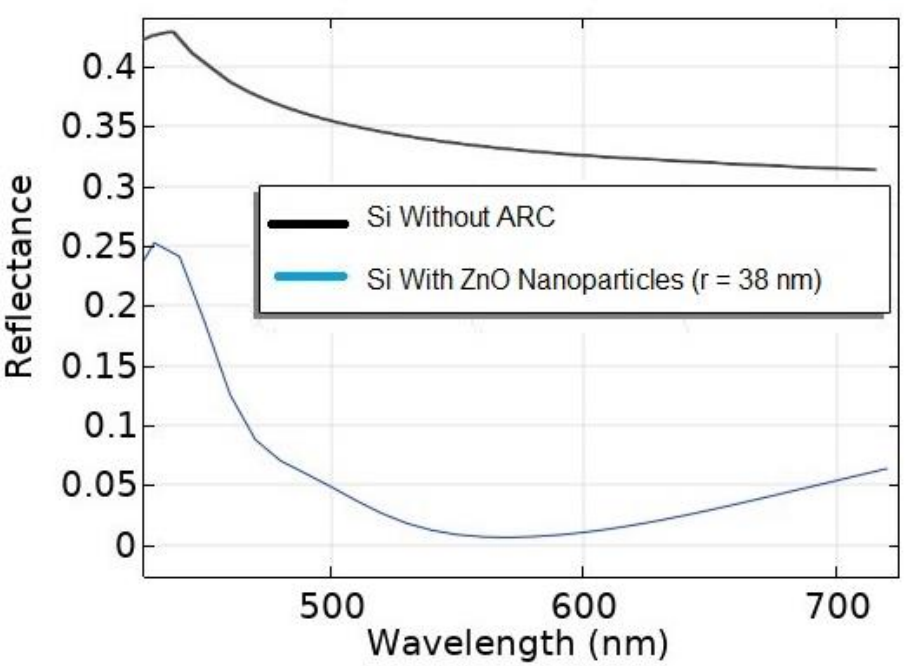

Figure 8. Reflectance spectra of $\mathrm{ZnO}$ nanoparticles with radius $38 \mathrm{~nm}$ for $\mathrm{Si}$ cell obtained by COMSOL Multiphysics model. 
Table 4. Average reflectance values of using $\mathrm{ZnO}$ nanoparticles with radius $38 \mathrm{~nm}$ as an ARC layer.

\begin{tabular}{cc}
\hline Interval (nm) & Reflectance \\
\hline $380-720$ & $5.5 \%$ \\
\hline $500-720$ & $2.3 \%$ \\
\hline $550-600$ & $\sim 0 \%$ \\
\hline
\end{tabular}

\section{Conclusions}

Silicon solar cells suffer from high reflection values due to their refractive index. Hence, reducing the reflection highly enhances the device performance. Antireflective coatings using nanomaterials can highly influence the reflection values, and bring down the surface reflection to near zero values to maximize the output power generated by Si solar cells. RSM-based optimization of the antireflection coatings by using the CCD method was used to evaluate and to optimize the effect of the nanoparticle types, radius of nanoparticles, and wavelengths to best reduce the reflection from the surface of $\mathrm{Si}$. Three different types of nanoparticles, namely $\mathrm{Al}_{2} \mathrm{O}_{3}, \mathrm{TiO}_{2}$, and $\mathrm{ZnO}$ antireflective coatings on $\mathrm{Si}$ substrates, were modeled numerically by using finite element simulation by solving the Maxwell wave equation for periodic nanostructure arrays. COMSOL Multiphysics software was used to perform the simulation by selecting the electromagnetic wave optics module. Various factors, including radius of nanoparticles and wavelength period, were studied in order to obtain better insight into how the light-matter interaction is affected by changing the nanomaterial types.

Between the studied nanoparticle types, $\mathrm{Al}_{2} \mathrm{O}_{3}$ provides the worst optical performance. The $\mathrm{TiO}_{2}$ nanoparticles show intermediate optical performance, while the $\mathrm{ZnO}$ nanoparticles were the best to reduce the optical reflection by decreasing the light reflection to near zero. The optimization process shows less than $5 \%$ reflection values over a wide spectral range, while reaching near zero reflection at $\sim 560 \mathrm{~nm}$ for a $38 \mathrm{~nm} \mathrm{ZnO}$ nanoparticle size, which can highly enhance the solar cell performance.

Author Contributions: Conceptualization, Y.F.M., H.A. and G.T.; methodology, Y.F.M., H.A. and G.T.; software, Y.F.M. and H.A.; validation, Y.F.M. and H.A.; formal analysis, Y.F.M., H.A. and G.T.; investigation, Y.F.M., H.A. and G.T.; resources, Y.F.M. and G.T.; data curation, Y.F.M., H.A. and G.T.; writing-original draft preparation, Y.F.M., H.A. and G.T.; writing-review and editing, Y.F.M. and G.T.; visualization, Y.F.M. and G.T.; supervision, Y.F.M., H.A. and G.T.; project administration, Y.F.M. and G.T.; funding acquisition, Y.F.M. and G.T. All authors have read and agreed to the published version of the manuscript.

Funding: This research was funded by the Deanship of Scientific Research at Jordan University of Science and Technology_Jordan, grant number 20190533, in addition to the Jordanian Royal Hashemite Court under Innovative Projects in Nanotechnology.

Data Availability Statement: The data presented in this study are available on request from the corresponding author. The data are not publicly available due to ongoing study.

Conflicts of Interest: The authors declare no conflict of interest.

\section{References}

1. Zheng, X.; Streimikiene, D.; Balezentis, T.; Mardani, A.; Cavallaro, F.; Liao, H. A review of greenhouse gas emission profiles, dynamics, and climate change mitigation efforts across the key climate change players. J. Clean. Prod. 2019, 234, 1113-1133. [CrossRef]

2. Xing, Y.; Han, P.; Wang, S.; Liang, P.; Lou, S.; Zhang, Y.; Hu, S.; Zhu, H.; Zhao, C.; Mi, Y. A review of concentrator silicon solar cells. Renew. Sustain. Energy Rev. 2015, 51, 1697-1708. [CrossRef]

3. Deshpande, R.A. Advances in Solar Cell Technology: An Overview. J. Sci. Res. 2021, 65, 72-75. [CrossRef]

4. Jiang, T.; Xu, X.; Chen, G.Z. Silicon prepared by electro-reduction in molten salts as new energy materials. J. Energy Chem. 2020, 47, 46-61. [CrossRef]

5. Lindroos, J.; Savin, H. Review of light-induced degradation in crystalline silicon solar cells. Sol. Energy Mater. Sol. Cells 2016, 147, 115-126. [CrossRef] 
6. Zarmai, M.T.; Ekere, P.N.N.; Oduoza, C.; Amalu, E.H. A review of interconnection technologies for improved crystalline silicon solar cell photovoltaic module assembly. Appl. Energy 2015, 154, 173-182. [CrossRef]

7. Arduca, E.; Perego, M. Doping of silicon nanocrystals. Mater. Sci. Semicond. Process. 2017, 62, 156-170. [CrossRef]

8. Zhang, H.; Wang, T.; Chen, W. Polyoxometalate modified all-weather solar cells for energy harvesting. Electrochim. Acta 2020, 330, 135215. [CrossRef]

9. Diop, M.M.; Diaw, A.; Mbengue, N.; Ba, O.; Diagne, M.; Niasse, O.A.; Ba, B.; Sarr, J. Optimization and Modeling of Antireflective Layers for Silicon Solar Cells: In Search of Optimal Materials. Mater. Sci. Appl. 2018, 9, 705-722. [CrossRef]

10. Singh, G. Solar power generation by PV (photovoltaic) technology: A review. Energy 2013, 53, 1-13. [CrossRef]

11. Salman, K.A. Effect of surface texturing processes on the performance of crystalline silicon solar cell. Sol. Energy 2017, 147, 228-231. [CrossRef]

12. Yin, Y.; Bu, Y.; Wang, X. PDMS-based subwavelength structures for broadband and wide-angle anti-reflection. Phys. B Condens. Matter 2020, 580, 411943. [CrossRef]

13. Pillai, S.; Green, M. Plasmonics for photovoltaic applications. Sol. Energy Mater. Sol. Cells 2010, 94, 1481-1486. [CrossRef]

14. Rehman, A.U.; Iqbal, M.Z.; Bhopal, M.F.; Khan, M.F.; Hussain, F.; Iqbal, J.; Khan, M.; Lee, S.H. Development and prospects of surface passivation schemes for high-efficiency c-Si solar cells. Sol. Energy 2018, 166, 90-97. [CrossRef]

15. Shinen, M.H.; AlSaati, S.A.A.; Razooqi, F.Z. Preparation of high transmittance $\mathrm{TiO}_{2}$ thin films by sol-gel technique as antireflection coating. J. Phys. Conf. Ser. 2018, 1032, 012018. [CrossRef]

16. Han, S.-Y.; Paul, B.K.; Chang, C.-H. Nanostructured $\mathrm{ZnO}$ as biomimetic anti-reflective coatings on textured silicon using a continuous solution process. J. Mater. Chem. 2012, 22, 22906-22912. [CrossRef]

17. Oh, S.J.; Chhajed, S.; Poxson, D.J.; Cho, J.; Schubert, E.F.; Tark, S.J.; Kim, D.; Kim, J.K. Enhanced broadband and omni-directional performance of polycrystalline Si solar cells by using discrete multilayer antireflection coatings. Opt. Express 2012, 21, A157-A166. [CrossRef]

18. Jung, J.; Jannat, A.; Akhtar, M.S.; Yang, O.-B. Sol-Gel Deposited Double Layer $\mathrm{TiO}_{2}$ and $\mathrm{Al}_{2} \mathrm{O}_{3}$ Anti-Reflection Coating for Silicon Solar Cell. J. Nanosci. Nanotechnol. 2018, 18, 1274-1278. [CrossRef] [PubMed]

19. Makableh, Y.F.; Al-Fandi, M.; Khasawneh, M.; Tavares, C.J. Comprehensive design analysis of ZnO anti-reflection nanostructures for Si solar cells. Superlattices Microstruct. 2018, 124, 1-9. [CrossRef]

20. Hocine, D.; Belkaid, M.; Pasquinelli, M.; Escoubas, L.; Simon, J.; Rivière, G.; Moussi, A. Improved efficiency of multicrystalline silicon solar cells by $\mathrm{TiO}_{2}$ antireflection coatings derived by APCVD process. Mater. Sci. Semicond. Process. 2013, 16, 113-117. [CrossRef]

21. Lin, J.-Y.; Zheng, Q.; Hu, C.-S.; Lin, Y.-A. Reduction of silicon surface reflection with micro-sphere texturing. In Proceedings of the 2017 International Conference on Applied System Innovation (ICASI), Sapporo, Japan, 13-17 May 2017; Volume 2017, pp. 509-511. [CrossRef]

22. Jo, H.-J.; Shim, B.-H. Efficiency enhancement of $\mathrm{Cu}(\mathrm{In}, \mathrm{Ga}) \mathrm{Se}_{2}$ thin film solar cells by employing onmi-directional $\mathrm{ZnO}$ nanostructure with $\mathrm{MgF}_{2}$ anti-reflection-coating layer. Microw. Opt. Technol. Lett. 2018, 60, 2634-2639. [CrossRef]

23. Ramelan, A.H.; Wahyuningsih, S.; Munawaroh, H.; Narayan, R. ZnO wide bandgap semiconductors preparation for optoelectronic devices. IOP Conf. Ser. Mater. Sci. Eng. 2017, 176, 012008. [CrossRef]

24. Ahmad, A.A.; Al-Bataineh, Q.M.; Alsaad, A.M.; Samara, T.O.; Al-Izzy, K.A. Optical properties of hydrophobic ZnO nano-structure based on antireflective coatings of $\mathrm{ZnO} / \mathrm{TiO} / \mathrm{SiO}$ thin films. Phys. B Condens. Matter 2020, 593, 412263. [CrossRef]

25. Bashirpour, M.; Forouzmehr, M.; Hosseininejad, S.E.; Kolahdouz, M.; Neshat, M. Improvement of Terahertz Photoconductive Antenna using Optical Antenna Array of ZnO Nanorods. Sci. Rep. 2019, 9, 1-8. [CrossRef] [PubMed]

26. BashirKhanabc, S.; Zhangd, Z.; Lee, S.L. Single component: Bilayer $\mathrm{TiO}_{2}$ as a durable antireflective coating. J. Alloy. Compd. 2020, 834, 155137. [CrossRef]

27. Юрпалов, В.Л.; федорова, Е.Д.; Дроздов, В.А.; Лавренов, А.В. Оценка кислотных свойств системВ $\mathrm{B}_{2} \mathrm{O}_{3}-\mathrm{Al}_{2} \mathrm{O}_{3}$ иРt $/ \mathrm{B}_{2} \mathrm{O}_{3}-$ $\mathrm{Al}_{2} \mathrm{O}_{3}$ методом зондовой ЭПР-спектроскопии и их корреляция с протеканием совместной гидроизомеризации гептана и бензола. Кинетика и Катализ 2016, 57, 548-553. [CrossRef]

28. Chaya, B.M.; Sharon Prarthna, C.; Vinith Kumar, G.P.; Krishnaswamy, N. Modeling and Analysis of Double Layer Motheye Anti Reflective Coatings on Organic Light Emitting Diode. In Proceedings of the 7th International Conference on Photonics, Prague, Czech Republic, 25-27 February 2019; pp. 190-195.

29. Refinery, N.P.; Braimah, M.N.; Odejobi, O.J. Utilization of Response Surface Methodology (RSM) in the Optimization of Crude Oil Refinery. J. Multidiscip. Eng. Sci. Technol. 2016, 3, 4361-4369.

30. Paulo, F.; Santos, L. Design of experiments for microencapsulation applications: A review. Mater. Sci. Eng. C 2017, 77, 1327-1340. [CrossRef]

31. Cao, B.; Adutwum, L.A.; Oliynyk, A.O.; Luber, E.J.; Olsen, B.C.; Mar, A.; Buriak, J.M. How to Optimize Materials and Devices via Design of Experiments and Machine Learning: Demonstration Using Organic Photovoltaics. ACS Nano 2018, 12, 7434-7444. [CrossRef]

32. Wang, Y.; Hang, L. Study on transmission spectrum and electric field distribution of graded-index anti-reflection coatings. In Proceedings of the 9th International Symposium on Advanced Optical Manufacturing and Testing Technologies: Meta-SurfaceWave and Planar Optics, Chengdu, China, 26-29 June 2019; Volume 10841, p. 1084112. 
33. Sivakumar, R.; Gopalakrishnan, P.; Razak, M.S.A. Comparative analysis of anti-reflection coatings on solar $\mathrm{PV}$ cells through TiO 2 and $\mathrm{SiO}_{2}$ nanoparticles. Pigment. Resin Technol. 2021. [CrossRef]

34. Mousavi, B.K.; Mousavu, A.K.; Busani, T.; Zadeh, M.H.; Brueck, S.R.J. Nanostructured Anti-Reflection Coatings for Enhancing Transmission of Light. J. Appl. Math. Phys. 2019, 7, 3083-3100. [CrossRef]

35. Al-Fandi, M.; Makableh, Y.F.; Khasawneh, M.; Rabady, R. Near zero reflection by nanostructured anti-reflection coating design for Si substrates. Superlattices Microstruct. 2018, 117, 115-120. [CrossRef]

36. Kazanskiy, N.; Butt, M.; Khonina, S. Silicon photonic devices realized on refractive index engineered subwavelength grating waveguides-A review. Opt. Laser Technol. 2021, 138, 106863. [CrossRef]

37. Elshorbagy, M.H.; Abdel-Hady, K.; Kamal, H.; Alda, J. Broadband anti-reflection coating using dielectric Si3N4 nanostructures. Application to amorphous-Si-H solar cells. Opt. Commun. 2017, 390, 130-136. [CrossRef]

38. Rezaei, N.; Isabella, O.; Vroon, Z.; Zeman, M. Optical optimization of a multi-layer wideband anti-reflection coating using porous $\mathrm{MgF}_{2}$ for sub-micron-thick CIGS solar cells. Sol. Energy 2019, 177, 59-67. [CrossRef]

39. Montgomery, D. C.; Runger, G.C. Applied Statistics and Probability for Engineers. Eur. J. Eng. Educ. 1994, 19, 383. [CrossRef]

40. Visser, D.; Chen, D.Y.; Désières, Y.; Ravishankar, A.P.; Anand, S. Embossed Mie resonator arrays composed of compacted TiO 2 nanoparticles for broadband anti-reflection in solar cells. Sci. Rep. 2020, 10, 1-11. [CrossRef] [PubMed]

41. Minemoto, T.; Mizuta, T.; Takakura, H.; Hamakawa, Y. Antireflective coating fabricated by chemical deposition of ZnO for spherical Si solar cells. Sol. Energy Mater. Sol. Cells 2007, 91, 191-194. [CrossRef]

42. Ilican, S.; Caglar, Y.; Caglar, M. Preparation and characterization of ZnO thin films deposited by sol-gel spin coating method. J. Optoelectron. Adv. Mater. 2008, 10, 2578-2583.

43. Lee, Y.-J.; Ruby, D.S.; Peters, D.W.; McKenzie, B.B.; Hsu, J.W.P. ZnO Nanostructures as Efficient Antireflection Layers in Solar Cells. Nano Lett. 2008, 8, 1501-1505. [CrossRef] [PubMed] 